Giovanni Rizzi

Pontifical Urbaniana University

giovanni.rizzi.ferruccio@gmail.com

\title{
African and Rwandan Translations of the Bible
}

The article will first, as an introduction, frame and circumscribe the meaning of what I will further develop and present regarding translations of the Bible in the geopolitical and ecclesiastical area of Rwanda. This will be followed by an overall look at translations of the Bible, or parts of it, on the African continent, based on the editions present in the Bibles Collection of the Urbaniana University Library. The specific treatment of the copies of the Bible translations in the geopolitical and ecclesiastical area of Rwanda will be both the focal point and the final point of my study.

\section{Introduction}

What I am presenting here is part of a larger project, developed in connection with the book heritage of the Library Fund of the Pontifical Urbaniana University ${ }^{1}$ (PUU), in view of the conference From the Urban

\footnotetext{
1 In the context of the Urbaniana University, the department of Biblical Theology, in the second and third cycle of studies dedicated to obtaining the Licentiate and Doctorate in Theology with Biblical Specialization respectively, has started a training project for several years, also extended to students of other universities, on the translation of the Bible into other languages. My study falls in this area.
} 
College to the Pontifical Urbaniana University: 375 years of history (Rome, 28-30 November 2002), since 2001 when I began studying the Collection of the Bible editions present in the Library of the PUU. ${ }^{2}$ The complex centuries-old history, through which the current heritage of the Bibles Collection of the PUU Library was established, has allowed for the formation of an enormous body of documentation on the inculturation of the Christian faith in the various areas of competence of the Dicastery of the Congregation for Evangelization of Peoples. This does not mean that the noticeable material is exhaustive [cf. Rizzi 2006], although it is certainly significant.

The inculturation of the Christian faith in the various areas of competence of the Dicastery of Propaganda Fide can be appropriately studied through two kinds of works that are certainly different, but also quite closely connected: translations of the Bible, or of some of its literary bodies, or even just of one of its books, into local languages, and catechisms. For the biblical scholar, both literary genres are significant: the translations of the Bible as documentation of a relationship with the linguistic and cultural archetypes on which they were conducted, and in relation to the languages and cultures for which they were intended, and the catechisms in their varied documentation over the span of about half a millennium, as they contain many references, quotations and allusions to biblical texts, of which they also constitute an important form of hermeneutics for popular use.

There are two preliminary issues in this area: the question of the multiplicity of languages and the need to circumscribe the area of texts to be examined.

\section{The multiplicity of languages}

Both for the editions of the Bible and for the catechisms, the heritage of the Library cannot be embraced from a linguistic and philological point of view by a single person, as a more than consistent group of scholars would be needed, whose constitution would not be easy, and rather complex to make work.

For modern Western languages, or for the "classical" languages of the Bible and its older versions, it was less difficult to gather a group of

2 An extremely valuable resource for this specific task is the University Library and the Propaganda Fide Archives, which can be accessed directly from the Urbanian University campus. 
scholars to start the project currently underway on Bible Translations. It might not be difficult to expand the current group of scholars, including those specializing in other ancient versions of the Bible.

However, having to embrace editions of the Bible and catechisms in all the ecclesiastical and geopolitical areas in which the Dicastery of Propaganda Fide operates, it was important to start, where it was possible, on the linguistic and philological knowledge currently available, but it proved essential to enhance at best all the information, far from scarce, almost always present in the introductions to the editions of the Bible and catechisms in modern Western languages. The linguistic and philological characterization of the translations and catechisms was quite clear.

\section{The need to circumscribe the area of the texts to be examined}

For the editions of the Bible in the Collection of the PUU Library, the study has already found 1,291 editions of the Bible, including complete editions of the biblical text of the OT and of the NT, editions of literary corpora of the Bible and even of individual biblical books, in 160 languages. It should be added that part of this material also comes from the missions of the Reformed Churches and of those belonging to the Orthodoxy. ${ }^{3}$

For the editions of the catechisms and related material, the Collection of the Library was suddenly enriched with the addition of a large corpus of catechisms coming from the Archives of the Dicastery of Propaganda Fide in Rome, so that an overall estimate of the entire collection of catechisms present in the same PUU Library would be around 18,000 volumes. After a patient manual survey, volume by volume, a corpus of catechisms relating to the African continent [Rizzi 2015] was published in 2015. More recently, a corpus of the Chinese catechisms found in the collection of the same Library was published [Rizzi, Zhao Hongtao, Raini 2019] after the patient work of a manual survey of all the volumes, whose previous paper classification was too brief and whose computerized cataloging was only planned. With the 350 volumes catalogued, it also constitutes the largest corpus of Chinese catechisms present in Italian libraries.

3 The digitalization work of the Library has been started; in the last sixteen years, however, this patrimony of Bible editions has been further enriched, with the advantage of being immediately and continuously updated through complex computerized cataloging. 
At this point, it was possible to outline the project of connecting the editions of the Bible with the related catechisms in the distinct continental areas under the responsibility of the Dicastery of Propaganda Fide. In fact, it was very clear that there was and still exists today a significant difference in the strategy of evangelization in the Catholic Church when compared to that of the Reformed Churches. For the Catholic Church, catechisms have always been the first means of evangelization, written in chronological order in the mission territories, followed later by the editions of the Bible. For the Reformed Churches, the strategy could be defined as exactly the opposite: first the editions of even a single biblical book and as soon as possible the entire Bible, then, subsequently, more "catechetical" editions of the Bible, in forms in some respects analogous to a genre very widespread on a popular level as well, such as Illustrated Biblical History or Sacred History, which is more prone to the use of selection and paraphrase of biblical texts [cf. Rizzi 2019: 49]. ${ }^{4}$

Two specific studies on the biblical contents of the catechisms studied for the African Continent and for the Directory of Chinese catechisms were sufficient to clarify that direct links between editions of the Bible and the catechisms cannot be specified, given the chronological and cultural distance between the various editions of the Bible and the catechisms, even within the same ecclesiastical and geopolitical area [cf. Rizzi 2017, 2019a]. This does not mean it is impossible to rediscover a connection between Bibles and catechisms, but that much more documentary material is needed, regarding both the editions of the Bible and the catechisms.

The research project could continue, but here I first provide an overall picture of the translations of the Bible on the African continent, and then move on to focusing on the Bible editions of the Rwandan ecclesiastical and geopolitical area.

\section{A possible overall picture of the editions of the Bible on the African continent}

In the PUU Library Collection, biblical material from the African continent constitutes a fairly substantial component, so an overall discussion is impossible. In fact, while for some geographical areas of Africa the

4 In fact, a similar phenomenon is found in the corpus of the Bible editions in the Dutch Indies, edited by the Netherlands Bible Society [cf. Rizzi 2006, Vol. 3: 1269-1270]. 
material in question concerns a single state, or simply a single ecclesiastical circumscription, with a single copy, for other areas the documentation concerns various states and ecclesiastical circumscriptions, and in some cases one geopolitical area alone presents such extensive documentation that it requires further specific segmentation.

Furthermore, in various cases the editions of biblical texts also reflect a long and complex political history of the country: the denominations of the Apostolic Vicariates and Dioceses and the names of the Bishops, who gave the imprimatur to an edition, reflect the historical evolution from mission to local Church; the different political denominations of the country, in the various editions after some time, ${ }^{5}$ are often affected by the history of western colonialism in Africa, up to the most recent events of political independence and its further developments.

Even the editions of the versions of biblical texts in local languages are affected by the biblical and theological culture of the churches, ordinarily European or in any case "Western", on which they depend, while not failing to highlight their own sensibilities.

It is still easy to record how for African cultures which did not yet have their own written tradition - but only or almost exclusively an oral tradition - the editions of the Bible or some of its literary corpora such as the Gospels, still in the $19^{\text {th }}$ century and not infrequently even in the $20^{\text {th }}$ century, were the first literary monuments in a local language, transliterated into Western characters, with possible additions of other forms of non-Western letters or with supra- or sub-linear signs. Furthermore, for a long time the literary archetype, from which the Bible, or one of its literary corpora, or even just one of its books was translated was the Latin Vulgate of Hieronymian origin, but in the non-critical form of the SixtoClementine in one of its possibly nineteenth-century editions. In not a few cases, the archetype was an English, or possibly French, translation of the Vulgate itself: an African translation from another European translation dependent on the Vulgate. In other cases, an edition of an "African" Bible from a certain area of the missions was the archetype of a new translation into another local African language.

The system of introductions or marginal notes could vary, at times very happily depending on the biblical-theological preparation of Western

The first publication concerning a biblical text in Falasha Kara dates back to 1885 [cf. North 1938: 28]. 
missionaries. Often the problem was to find the correspondence between the expressions and concepts of the original biblical archetypes and the language into which it was necessary to translate: in this context the formula of cultural equivalents has had some success, even accepting making long paraphrases or reformulations compared to the biblical original, in order to make itself understandable to the Christian population to which one had to turn.

The translators of many editions of the Bible into an African language were also Westerners: French speakers, Anglophones, Flemish, Germans, and even Italians. Ordinarily only several years after the Second Vatican Council, the translators of the Bible into an African language were Christians, priests or religious, and indigenous. In more recent times, a modern biblical-exegetical culture has come to be noted, like that ordinarily taught in European or Western universities, of African translators, increasingly committed to translating from biblical texts into their original languages, also using critical editions of the Hebrew and Greek text.

The modern scientific model of Western biblical exegesis is for now still dominant in the most recent and updated editions of the Bible, translated from biblical archetypes into their original languages, when it is not exclusive. It will therefore be the task of the new generations of "African" biblical scholars to draw an overall picture between the first editions of the Bible in an African language and the latest developments on the subject, also in light of the internal evolution of the various African languages. With the current patrimony of the Bible editions of the Collection of the Library of the PUU, we are unable to trace a significant relationship between the editions of the Bible of the Catholic Church and those coming from the Reformed Churches on the African continent.

The only real and great exceptions in the matter of editions of the Bible in Africa are the documentation of the editions of biblical texts in the Coptic $^{6}$ and Ethiopian ${ }^{7}$ languages. In fact, the Coptic Church and the Ethiopian Church have very ancient roots, which go back to the Apostolic Churches and the great Patriarchates, so as to be considered in the Christian Tradition among the Oriental Churches [Cf. Guillaumont 1993: 9-13]. Their deep, two-thousand-year-old roots in patristic traditions have given a completely different imprint to their editions of biblical texts, not only compared to

A book patrimony, also bilingual (Coptic-Arabic), comprising 27 volumes.

A book patrimony in Ancient Geez and Amharic comprising 24 volumes. 
those of other African Churches, but also to those of the European and Western Churches. Moreover, the ancient Coptic and Ethiopian versions of the Scriptures belong to those languages in which the first great and systematic versions of the Scriptures from Greek, one of the original and constitutive languages of the Scriptures themselves, were rendered.

Based on the material available in the Collection of the Library, the African continent can be divided into seven large geographical areas: two volumes in one language belong to North Africa; 17 volumes involving seven languages belong to West Africa; 17 volumes in five languages belong to Northeast Africa; 18 volumes involving eight languages belong to East Africa; 65 volumes involving 13 languages belong to Central Africa; and ten volumes involving nine languages belong to Southern Africa.

Overall, it is a book patrimony of 180 volumes of Bible translations involving 47 languages [Cf. Rizzi 2006, Vol. 3: 1295-1296].

Of this book heritage, my report now deals with the editions of the Bible in the ecclesiastical and geopolitical area of present-day Rwanda, part of central Africa.

\section{Rwandan translations of the Bible}

According to the catalogue of the American Bible Society, the first publication concerning a biblical text in the "Rwanda" language is from 1914, while the first edition of the NT is from 1931 [Cf. North 1938: 31].

More recently and on an exegetical level, I. Himbaza, collaborator at the University of Freiburg on the Biblia Hebraica Quinta (BHQ) project, has dealt with the question of the translation of the Old Testament in the editions of the Bible in Rwanda [Himbaza 2001]; he examined the wider context of the recipients of the translations: their cultural and linguistic particularities, and their ways of thinking. He compared the translation of the OT of the Reformed Churches and that of the Catholic Church, starting with the Masoretic Hebrew text to observe the two translations in Kinyarwanda, looking at those in French into English which inspired them, and took into account the exegesis and current textual criticism. ${ }^{8}$ In

8 The material for a comparison with the Reformed Churches Bible editions consists of the complete translation into Kinyarwanda published between 1914 and 1957, the Biblia Yera (1993) of the Societé Biblique du Rwanda, the interconfessional translation of the NT in Kinyarwanda, published in Kigali (1989) and always edited by the Societé Biblique du Rwanda. For the Catholic Church Himbaza took into consideration the 
a personal interview with Prof. Himbaza, in the context of a conference on Bible translations at the PUU, he exemplified one of the fairly frequent cases in other African languages, when compared to the biblical archetype: a designated object has no possible correspondences in the language into which it is being translated. Specifically, we have taken into consideration the translation of "vine", or "vineyard", which given the altitude cannot grow in Central Africa, with specific reference to the Congo area. In cases like this, until a while ago it was possible to resort to local cultural archetypes through cultural equivalents, profoundly transforming not only the formulation but also the image of the biblical archetype. Today it seems to be preferable to render a literal translation of the term, "confusing" in the language in which it is translated, resorting in a note to a sketch of the object in question and a specific caption.

The documentation relating to Rwanda consists of five copies in the Kinyarwanda language, ${ }^{9}$ belonging to two editions of the NT and one edition of the OT-NT.

\section{The first edition of the NT in Kinyarwanda}

In chronological order, the first edition of the NT, in two copies, (1988), ${ }^{10}$ printed in Spain and inserted in the distribution network of Verbum Bible (Congo-Kinshasa) with regular authorization of the ecclesiastical authority of the local Church, ${ }^{11}$ is the result of a revision ${ }^{12}$ of the original texts. The

Biblia Ntagatifu, distributed by Verbum Bible in Kinshasa (1990) in Zaïre, now Congo, but printed in Spain.

9 An edition in two copies of the entire NT (1988); one complete edition of the NT (1989); two complete editions of the OT-NT $(1990,1992)$.

10 Original title: Isezerano Rishya (1988), Verbum Bible, Barañain (Navarre); in a manual pen notation on an inside page: "New Testament in Kinyarwanda"; one copy has a red plastic-coated cover; in the other copy, with an indigo-blue plastic cover, an accompanying printed sheet appears: "Verbum Bible / Societé du Verbe Divin au Zaïre ASBL - B.P. 7463 / Kinshasa / Zaïre. / Verbum Bible vous présente ISEZERANO RISHYA, une révision approfondie du NT en Kinyarwanda, réalisée par la Commission épiscopale pour la Traduction de la Bible. / Exemplaire gratuit à titre d'information". 11 Obras Misionales Pontificias de España / Jungschar (Austria) / Imprimatur: Kabgai le 14 janvier 1988 / A. Perraudin Archorègue - évêque de Kgabai Président de la Commission épiscopale liturgique et catéchétique.

12 The names of the members of the revision team are indicated: P.L. Gombarino, Myr. S. Habyarimana, P.I. Kanyegana, Bw. J. Karasina, P.C. Kalisa, Myr. V. Linguyeneza, P.A. Misago, P.R. Tardif, P.G. Theunis, P.J. Van der Meersch, and Myr. L. Vermeersch. 
group of translators is now mixed, being made up of Western and African biblical scholars.

The text of the NT is regularly divided into chapters, verses and minor pericopes, with specific titles according to the orientations of modern criticism; the biblical books are reported according to the canonical order and the text is transcribed from Kinyarwanda in completely Western characters. ${ }^{13}$ The work still certainly has pastoral purposes, but with good and timely updated aids of a modern scientific nature.

The volume opens with the general index of the NT; a caption on the quotations from the NT follows, and a caption on the abbreviations of the Old Testament; there is a brief general introduction to the NT [Isezerano Rishya 1988: 5-10]; here and there appear some photographs of the classic genre of places of the Holy Land (few in the span of the entire edition). The introductions to the individual biblical books are partly traditional and partly historical-critical modern. The general chronology of the writings of the NT is established according to historical-critical criteria.

The books of the NT are grouped into three blocks: Gospels and Acts, Corpus paulinum, Letters and Revelation. A brief introduction and schematization of each Gospel is followed by the translated text [Isezerano Rishya 1988: 11-395].

The (possible) Synoptic and Johannine parallels in the Gospels are combined with the subdivisions into pericopes with their related titles; explicit quotations of the Old Testament in the Gospels are given in italics, or even in italics and indented; and the extremes of the quotations from the OT and the intertextualities with the NT and the OT in the Gospels are reported in the footnotes, which are quite frequent and extensive.

A brief introduction and outline of the Acts is followed by the translated text of the Acts [Isezerano Rishya 1988: 396-498]. The explicit quotations of the OT in the Acts are given in italics, or even in italics and indented; the extremes of the explicit quotations of the OT in the Acts and very few intertextualities with the NT appear in the footnotes, which are much more concise and rarer.

A slightly broader introduction is intended for Paul and the Corpus paulinum, while the introduction to each single letter is short: overall the Corpus paulinum with the individual introductions occupies a considerable

13 Cf. also the enumeration of pages, chapters, verses and notes; biblical language and culture of reference is French. 
space [Isezerano Rishya 1988: 499-804]. The quotations of the OT in the Corpus paulinum are given in italics, or even in italics and indented; the extremes of the explicit quotations of the OT in the Corpus paulinum appear in the notes, although there the intertextualities with the Corpus paulinum and with the NT are much more numerous. The notes in the Corpus paulinum are more numerous and more extensive than those in the Acts.

Each single Catholic Epistle and the Revelation are prefaced with a brief introduction, so that the entire literary corpus, including the introductions and translations of biblical texts, occupies a smaller space than the other sections of the NT [Isezerano Rishya 1988: 805-928]. Intertextuality, frequency and extension of the notes in the corpus of the Catholic Epistles and Revelation decrease.

The concluding part of the volume includes a general chronology of the NT and a general chronology of the writings of the NT [Isezerano Rishya 1988: 929-930], a map of Palestine, a map of the Mediterranean in NT times, and a liturgical calendar of the biblical readings according to the three-year cycle [Isezerano Rishya 1988: 931-940].

\section{The interconfessional edition of the NT}

Just a year later (1989) the interconfessional and common language Kinyarwanda $\mathrm{NT}^{14}$ appeared, printed in England, ${ }^{15}$ but published in Kigali by the local Bible Society. The text, transcribed from Kinyarwanda in completely Western characters, ${ }^{16}$ regularly follows the canonical order of the books and evidently has a pastoral purpose. The general index is followed by a general preface, then the captions for use and abbreviations [Inkuru Nziza ku Muntu Wese 1989: III-VIII]. The text is accompanied by some didactic drawings; each NT book is preceded by a very brief historicalcritical introduction with a schematization of the work. The explicit quotations of the OT are generally reproduced in quotation marks and indented, while the extremes of the quotations from the OT and any other type of

\footnotetext{
14 Original title: Inkuru Nziza ku Muntu Wese - Isezerano Rishya mu Kinyarwanda (1989), Umuryango wa Bibliya mu Rwanda, Kigali - Le N.T. en Kinyarwanda courant et interconfessionel, Alliance Biblique Universelle, UBS-EPF, Société Biblique au Rwanda, Kigali Rwanda.

15 Typeset in Great Britain by Latimer Trend \& Company Ltd, Plymouth.

16 Cf. also the enumeration of pages, chapters, verses and notes; biblical language and culture of reference is French; however onomastics and toponymy tend to be reproduced without specific references to Western languages.
} 
intertext are indicated in the footnotes. Notes are generally very short; the divisions of the text into pericopes follow the criterion of modern criticism and in the Gospels they also bear the Synoptic and Johannine parallels, while the parallels of the NT in the subdivisions disappear from the Acts for the rest of the NT.

There are well-updated aids of a modern scientific nature: an analytical index with names, places and concepts, a chronological table of the NT, an onomastic and toponymic index, a map of Palestine in the time of Jesus, a map of the Mediterranean in the times of the NT, and a map of Jerusalem in the time of Jesus [Inkuru Nziza ku Muntu Wese 1989: 521-543].

The interconfessional edition, corresponding to just over half of that of about ten years earlier, proves to have even more extensive pastoral purposes, given precisely its characterization as an "interconfessional" edition as well.

\section{Manual editions of the Bible}

A year later (1990) an edition of the OT-NT was published in Kinyarwanda: ${ }^{17}$ it was printed in Spain ${ }^{18}$ and inserted into the distribution network of Verbum Bible (Congo-Kinshasa) with regular authorization from the ecclesiastical authority of the local Church. ${ }^{19}$ Evidently this edition proves to be a new and independent work, also as regards the NT, certainly when compared to that of 1989 and to a large extent to that of 1988 as well. The new translation ${ }^{20}$ is also carried out on the original texts and strictly follows the canonical order of the books of the Catholic Church.

\footnotetext{
17 Bibiliya Ntagatifu (1990), Barañain (Navarra), Verbum Bible, Kinshasa Zaïre.

18 See also the inserted card on the origin of the shipment: "Obras Misionales Pontificias, Madrid".

19 Imprimatur: Kigali, 15 Mata 1990 (bishop's stamp and signature) † Joseph Ruzindana umushumba wa Diyosezi ya Byumba / Perezida w'Inama y'Abepiskopi bo mu Rwanda / Bibliya Ntagatifu / Myr. Anederya Perraudin, Arkiepiskopi-Umwepiskopi a'icyubahiro wa Kabgayi.

20 The names of the translation team are indicated, which had already partially participated in the edition of the NT 1988. "Abo ni aba: P.L. Gombaniro; Myr. S. Habyarimana; P.C. Kalisa; P.I. Kanyegana; Myr. V. Linguyeneza; P.A. Misago; Myr. Fr.X. Niyibizi (†); P.Th. Rubinigiza; P.D. Sekamana; P.R. Tardif; P.G. Theunis; P.J. Van der Meersch; P.L. Vermeersch. Babifashijwemo ku buyo bw'umwihariko na: Bw. Th. Gasama; Bw. J. Kararisa; Madamu M. Numukobwa; Bw. A. Nzaramba na Madamzela T. Uzamukunda".
} 
The pastoral purposes are evident: there is a table of the liturgical pericopes of the Bible according to the three-year cycle [Bibiliya Ntagatifu 1990: 2193-2216]; evangelical parallels recur in the titles of the pericopes in all the Gospels; the explicit quotations of the OT in the NT are in italics and indented, while the extremes of the explicit quotations are in the footnotes. The biblical text is divided into pericopes, as well as into chapters and verses, with titles according to today's criteria of the Western tradition; the notes, at the foot of the page and according to the numbering of the verses, are of a historical-philological, didactic and also theological nature, with copious intertextual references to the OT and NT. There are numerous photographs of the Holy Land with captions in Kinyarwanda, and the icon of the Pantokrator appears at the end.

There is methodical and accurate scientific updating. There is, in fact, a general introduction to the entire scriptural corpus, historical-critical and hermeneutic-theological in nature. There are also various geographical and partly topographical maps, ${ }^{21}$ and a chronological table of biblical history [Bibiliya Ntagatifu 1990: 7-12, 2179-2192].

The presentation of the literary corpora of the OT books is very wellarticulated. There is a general introduction to the Pentateuch with a general outline of the books, a modern historical-critical approach and elements of the New Testament hermeneutics of the Old Testament [Bibiliya Ntagatifu 1990: 15-18]. A general introduction to Genesis follows with schematization of the work and elements of the New Testament hermeneutics of the Old Testament; for each book of the Pentateuch there is a specific introduction; only for Genesis - Exodus, however, in the specific introduction an explicit New Testament hermeneutic of the Old Testament appears with intertextuality; then comes the translated text of the Pentateuch [Bibiliya Ntagatifu 1990: 19-309].

Note the general introduction to the corpus of the Former Prophets; each book has its own brief introduction. Starting from 1 Sam 31:1 up to and including 2 Kings, parallels with 1-2 Chronicles can also be noted in the titles of the pericopes. The chronology of the kings appears in the titles of the pericopes. Starting from 2 Kings 18:13, parallels with Isaiah also appear in the titles (cf. Sennacherib, etc.). The section of the Former

21 Maps of the fertile crescent, of the tribes of Israel, of Sinai, of the Palestine of the monarchical era, of Jerusalem of the monarchical period, of the Palestine at the time of Jesus, of Jerusalem at the time of Jesus, of the eastern Mediterranean in the HellenisticRoman period, and two maps on Paul's travels. 
Prophets occupies a substantial space, even with the translated text of the books that comprise it [Bibiliya Ntagatifu 1990: 310-574].

A general historical-editorial introduction to the corpus of the Historiography of the Chronicler follows, each book with its own brief introduction. In the notes and introduction to the corpus of the Historiography of the Chronicler the intertextuality with the NT disappears; starting from $1 \mathrm{Chr}$ 10:1 up to the end of 2 Chronicles, in the titles of the pericopes the parallels with 1-2 Samuel and 1-2 Kings appear; for $2 \mathrm{Chr} 36: 22-23$ the parallelism with Ezr 1:1-3 is also indicated. As well, in 2 Chronicles the chronology of the kings appears in the titles of the pericopes; for Ezra and Nehemiah the reciprocal parallels in the titles can be noted, with some chronological elements. The prayer of $\mathrm{Ne} 9: 5 b-37$ is reported in stichometric form. The section of the Historiography of the Chronicler occupies as a whole, even with the translated text of the books that compose it, a substantial space [Bibiliya Ntagatifu 1990: 575-701].

An introduction to the more specific literary genre of Tobias, Judith and Esther follows, distinct from that of the previous historiographical corpora. Each book has its own brief introduction; in the introductions and in the notes to the books of Tobias, Judith and Esther, in addition to the literary genre, biblical intertextualities and references to extra-biblical literature are highlighted. The specific parts of the LXX are indicated in the introduction to Esther. This section of the literature occupies a minor space within the translated text [Bibiliya Ntagatifu 1990: 702-761].

A general, historical introduction to 1-2 Maccabees follows, with a historical-literary introduction to each book. In the titles of the pericopes of 1-2 Maccabees the reciprocal parallels appear, with elements of absolute chronology.

Overall, the entire corpus text of the Historical Books, according to the more classical denomination of the Christian tradition, alternates denominations and classifications partly derived from the Hebrew Bible, partly from the LXX and the Christian tradition, but also from modern exegesis: in fact instead of titling the section including the books of Joshua, Judges, 1-2 Samuel, and 1-2 Kings, Deuteronomistic Historiography, the Hebrew name of Former Prophets was preferred. On the other hand, the characteristic sequence of the corpus of the LXX and of the Christian tradition for the Historical Books is respected, while also underlining the specificity of the literary genres of the various literary corpora that compose them: Historiography of the Chronicler, a distinct treatment of the "historical 
novels" of Tobias, Judith and Esther, and a separate treatment for 1-2 Maccabees, so that the entire section of the Historical Books with the translated texts occupies a larger space than the previous literary corpora [Bibiliya Ntagatifu 1990: 312-843].

The literary corpus of the Wisdom Books follows the classical framework of the Christian tradition. It opens with a general introduction to the Wisdom Books, but each book also has its own specific introduction; elements of New Testament hermeneutics appear in the general introduction to the Wisdom Books, with various intertextualities. In Job the order of the chapters also follows the reconstructions of modern criticism (cf. sequence Job 24ff.). More extensive than the others is the introduction to the Psalms, which follows the criterion of the literary genres, with final elements of Christological hermeneutics; each psalm has its own specific thematic title, in addition to that of the MT; the numbering of the Psalms follows the scansion of the MT, with the numbering of the LXX in parentheses. In the introduction to Proverbs, in addition to the more classic subdivisions proposed by the critics, a specific hermeneutical and intertextual treatment with the NT, especially with the evangelical genre, is reported; a similar tendency to intertextuality with the NT appears in the notes to Proverbs. In the introduction to Qoheleth, a specific treatment appears with peritestamentary hermeneutics and with direct intertextualities also with the NT. In the introduction to the Song of Songs a metaphorical conjugal reading of Hosea, Jeremiah, and Ezekiel also emerges; in the division of the text of the Song of Songs the characters who speak are indicated from time to time. Overall, the section of the Wisdom Books, also including Wisdom and Sirach and the translations of the biblical books, occupies a very substantial space [Bibiliya Ntagatifu 1990: 844-1273].

In the section dedicated to the literary corpus of the Prophets, the structure is that of the Jewish tradition, but is also at the same time Christian: first the four Major Prophets and then the Twelve Minor Prophets. The section begins with a general introduction to the Prophets: prophets, action prophets, writing prophets, and theological aspects. The approach is historical-critical, also highlighting the New Testament hermeneutics and explicit and numerous intertextualities; every single book has its own specific introduction.

For Isaiah the three parts identified in the now classical modern exegesis are indicated. Aspects of the New Testament re-readings of Prophets emerge both in the introductions and in the notes to the text. In the text of 
Jeremiah the changes in the people who speak are made explicit. Jeremiah is followed by Lamentations and Baruch (which includes the Letter of Jeremiah); for $J r 52$ in the title of the pericope the parallels with 2 Kings and with $J r$ 39:1-10 are indicated. Daniel, with the canonical additions of Susanna and Bel and the Dragon, comes after Ezekiel. The literary corpus of the Prophets, from Isaiah to Malachi including the translated texts, occupies a very substantial space [Bibiliya Ntagatifu 1990: 1274-1744].

The NT is also divided into literary corpora. It opens with a NT directory, and a general historical and theological introduction to the Gospels follows; there are therefore introductions to the individual Gospels. The translated text of the Gospels is presented continuously. A distinct and specific introduction to the Acts of the Apostles is followed by the translated text of Acts. A general historical-critical introduction to Paul and the Corpus paulinum follows; each letter of the Corpus paulinum has a historical-critical introduction. The translated text of the Corpus paulinum is reported continuously. For the corpus of the Catholic Letters there are only introductions to the individual letters; the translated text of the Catholic Letters is reported in the traditional order. After an introduction to the Revelation the translated text of the Revelation follows. Overall, the corpus of the NT occupies a fairly consistent space [Bibiliya Ntagatifu 1990: 1745-2178], although its treatment seems to be less elaborate than that of the OT.

Two years later (1992) an edition of Ebibliya Ntagatifu ${ }^{22}$ was published, with the same characteristics as the previous one.

\section{Conclusions}

If the editions of the Bible present in the ecclesiastical and geopolitical area of Rwanda represent only a small segment of the detectable documentation of the African continent in the Collection of the PUU Library, they certainly represent a very advanced stage of modern studies of exegesis and Biblical Theology, especially in relation to other ecclesiastical and geopolitical areas of the same continent. At the same time, their dating, although going back to the end of the last century, still does not allow us to fully grasp the evolutionary arc of all the editions of the Bible in that ecclesiastical and geo-political area.

22 Ebibliya Ntagatifu (1992), Verbum Domini, Kinshasa-Bukavu. 
The gap of about a dozen years between the first edition presented (1988) and the last (1992) reveals some characteristic features. The NT seems to be the first object of interest both in the context of the Catholic Church and in that of the Reformed Churches, until it appears in an interfaith edition (1989). The pastoral purposes are clearly evident in these editions of the NT, now also characterized by the translation into Kinyarwanda of the original texts.

It is probably the editorial experience acquired, together with a clear linguistic and historical-cultural technical competence in the exegetical field, which leads to the very detailed care evident in the two editions in a single volume of the OT-NT $(1990,1992)$, up to give a much more articulated structure to the same OT also in relation to the NT. The same acquisition of categorizations of the literary bodies of the Old Testament, mixing Jewish and Christian categorizations, highlights a situation in an open search for a more adequate understanding of biblical literature, from a confessional and interconfessional, if not strictly interreligious, perspective.

\section{References}

Ebibliya Ntagatifu (1992), Verbum Domini, Kinshasa-Bukavu.

Bibiliya Ntagatifu (1990), Verbum Bible, Kinshasa.

Inkuru Nziza ku Muntu Wese: Isezerano Rishya mu Kinyarwanda cy'iki gihe (1989), Umuryango wa Bibliya mu Rwanda, Kigali - Le N.T. en Kinyarwanda courant et interconfessionel, Alliance Biblique Universelle, UBS-EPF, Société Biblique au Rwanda, Kigali.

Isezerano Rishya (1988), Verbum Bible, Kinschasa.

Gieniusz, A., Spreafico, A. (2008), La Bibbia nelle Culture dei popoli. Ermeneutica e Comunicazione, U.U.P., Città del Vaticano.

Guillaumont, A. (1993), Introduction. L'Orient chrétien, in M. Albert, R. Beylot, R. G. Coquin, B. Outtier, C. Renoux, A. Guillaumont, Christianismes Orientaux. Introduction à l'étude des langues et littératures, Cerf, Paris.

Himbaza, I. (2001), Transmettre la Bible : une critique exégétique de la traduction del'A.T. : le cas du Rwanda, U.U.P., Città del Vaticano.

Himbaza, I. (2008), "Les enjeux de la traduction de la Bible eu Rwanda" in A. Gieniusz, A. Spreafico, La Bibbia nelle Culture dei popoli. Ermeneutica e Comunicazione, U.U.P., Città del Vaticano, 93-114. 
North, E. M. (1938), The Book of a Thousand Tongues, Being Some Account of the Translation and Publication of All or Part of the Holy Scriptures into more than a Thousand Languages and Dialects with over 1100 Examples from the Text, Harper \& Brothers, New York-London.

Rizzi, G., Zaho H., Raini E., Sileo L., (2019), Repertorio dei catechismi cinesi nella Biblioteca della Pontificia Università Urbaniana, U.U.P., Città del Vaticano.

Rizzi, G., (2019a) “Aspetti dei rapporti con le altre confessioni cristiane, con le altre religioni e l'inculturazione della fede nella formazione dei missionari e dei catechisti in Cina", Urbaniana University Journal 2 (2019 LXXII Nova Series).

Rizzi, G. (2019b), Bibbia, in Dizionario storico tematico. La Chiesa in Italia, F. Lovison, ed., Vol. I - L. M. De Palma, M. C. Giannini (eds.), Dalle origini all'Unità Nazionale, AIPSC, Roma.

Rizzi, G., (2017) "La Bibbia nei catechismi del continente africano presenti nel Fondo della Biblioteca della Pontificia Università Urbaniana", Urbaniana University Journal 3 (2017 LXX Nova Series).

Rizzi, G. (2015), Il corpus dei catechismi nel Fondo della Biblioteca Urbaniana di Propaganda Fide, Voll. 1-3, U.U.P., Città del Vaticano.

Rizzi, G. (2006), Edizioni della Bibbia nel contesto di Propaganda Fide. Uno studio sulle edizioni della Bibbia presso la Biblioteca della Pontificia Università Urbaniana, Voll. 1-3: Vol. 1 -Edizioni nelle lingue costitutive della Bibbia; Vol. 2 - Il continente europeo; Vol. 3 - Asia, Oceania, Africa, Continente Americano, U.U.P., Roma.

\begin{abstract}
The article offers a concise presentation of the project linked to the Library Fund of the Pontifical Urbaniana University, namely, to study the inculturation of the Christian faith by relating the documentation on the editions of the Bible to the catechisms in the territories entrusted to the pastoral care of the Congregation for Evangelization of peoples. The vastness of the project itself is marked today by the difficulty of using more extensive documentation than that present in the Fund of the same Library. However, more limited segments of the indicated material of interest can already be identified. More specifically, the African continent shows quite a varied phenomenology of the editions of the Bible: from translations of the Latin Vulgate into local languages, to translations from English or French, themselves translations from Latin. In the post-conciliar period,
\end{abstract}


the translations of the Bible from the original biblical languages emerge. This is the case of the Kinyarwanda versions of the NT $(1988,1989)$ and of the OT-NT in a single volume $(1990,1992)$, in which, alongside pastoral purposes, the results of modern biblical exegesis are evident, to the point of proposing categorizations of literary bodies of biblical literature from an interconfessional and also interreligious perspective.

Keywords: inculturation, Bible, Catechism, translations, Kinyarwanda 